\title{
Game Traditions: Lessons for Life
}

\author{
Jann Lacoss, University of Virginia
}

Vyshel ezhik iz tumana

Vynul nozhik iz karmana

Budu rezat', budu bit' -

Vse ravno tebe vodit' (1)

We all recognize the call to play, the start of a game. The counting-out rhyme signals the beginning of a social structure that mirrors, to a certain extent, the society in which its players live. Games help children prepare for adult life and for emotions associated with interacting in the adult world. Scholars have studies games with regard to socialization and the lessons that they instill in children about real life; as remnants of (often religious) ritual that is no longer practiced; and as reflections of historical and social events. I will look at some games that are currently played in Russia, putting them in perspective with regard to all of these interpretations.(2) My goal is to postulate what the perpetuation of these games reveals in this time of changing culture. Why do children play the same games that their parents (and possibly grandparents) played? What messages, social and otherwise, are children communicating to each other to and about their society?

\section{GAMES AND VALUES}

Games hold several characteristics in common and fulfill certain developmental functions for the children who play them. For example, they allow children an outlet to relieve tension and aggressions.(3) They also teach and build several skills, including strategy, rule-making and physical strength. They mirror real life more closely than do organized sports allowing much more flexibility in organization and rules, and they encourage self-expression.(4) Games such as "Tretii Lishnii" (Three's a Crowd) or "Priakki" (Hide and Seek) exemplify such versatility, as different play groups employ different rules for them. If three individuals (adults or children) from disparate regions are asked how to play any of these games, each will likely describe different rules or try to "correct" the others' variants. This indicates that the rules are flexible and reflect the ideals of each individual play group. Such versatility is especially characteristic of folklore.

Play also provides the opportunity to exercise control.(5) Games permit controlled disorder, that is, disorder within the predetermined or agreed-upon guidelines. When playing, children can run seemingly amok, as long as they remain within the boundaries set by the rules. Rule breakers are chastised and/or excluded from further play. Games also permit children to mock conventional 
roles.(6) Within the structure of the game, children assume the role of mother, bride, child, village aggressor, or oppressed. For example, in the American game "Mother, May I?" one child assumes the role of mother, exercising control over the other players. In playing these roles, children may choose to mock them. This affords the players a chance to vent often sublimated emotions associated with their appointed roles in life. "Priatki," for example, deals to a certain extent with separation anxiety. Although the goal is to avoid capture, the allure of the game lies in the players' confidence that someone cares that they are missing and will look for them. This parallels the emotions associated with leaving the family temporarily (e.g., to go to school). As in the game, children believe that they will be missed and someone will seek them if they do not return. Whereas in the adult world parents may chastise children for ridiculing adult roles or for making fun of their elders, games provide an appropriate venue to couch such acting out. In mocking roles, children usually do one of two things: play the actual role relatively appropriately (i.e., act out their perception of how an adult would act) or reverse the normative role (i.e., act out the role in a manner directly opposite to the expected norm). This is significant, in light of the fact that play also allows children to prepare for roles that they will play in life. Even through reversals, games reflect real life and are models of a larger system of power. Reversals refer to acting out the opposite of socially-accepted behavior. Reversals reinforce social norms by showing how life should not be.

In looking at the games that children play at any given time, one must take into account the society that influences them. To a certain extent, individuals reflect the societies in which they live. Behavior, according to Mary Douglas, is a result of social programming. Society teaches the individual to do everything.(7) Moreover, individuals reflect the larger society of which they are a part. Douglas theorizes that cultures tend to define themselves in terms of the relationship between the individual in society and the group.

Russian society has traditionally been highly structured. That is, there have always been official and unofficial rules governing behavior. During the pre-Soviet period, Russian culture favored the group over the individual, as evidenced by family and village life. Soviet culture built upon that, expanding and redefining the "group" to include all of society. Using Douglas' classification system, Russia can be categorized as grid weak and group strong, indicating that the larger group (society) holds greater influence and importance than the individual (grid).(8) In recent years, Russian society has been experiencing a shift, with the individual gaining greater importance. With the change to a market economy and the "official" establishment of a middle class, there has also been a rise in emphasis on the individual. It appears, however, that the group as an institution has 
retained its status. This raises a question as to the relationship of folklore to society. As society is changing to a more even pairing of group and individual importance, what social values remain significant to children? They are playing the same games that their predecessors played when society theoretically had a different focus. What aspects of behavior are children trying, on a subconscious level, to maintain?

\section{TRADITIONAL GAMES}

Russian children's folklore includes hundreds of games. For this study, I have chosen a few that have deep roots in Russian culture, dating back at least several generations. These games have not changed significantly over time and remain enduringly popular. Children still play all of the games to be discussed. While several other games also reflect the significance of the group, 1 have selected three as typical of the different types of children's games to be discussed. As an example of a game for smaller children, I have chosen "Gusi-gusi" (Geese-geese).(9) This type of game is typically played by children aged 5-8. Several similar games exist, all with similar goals. These include tagging players and incorporating them into a different group.(10) The players start by choosing the leaders, a "mama goose" and a "grey wolf." Once the vedushchie (leaders) are chosen, the game begins. To start the game, the mama goose stands at one end of the playing field. The goslings (all of the children besides the mama and the wolf) stand at the other end. The wolf remains in the middle of the field. The mama and her goslings engage in a poetic interchange:

$\begin{array}{ll}\text { Mama: Gusi, gusi! } & \text { Goosey, goosey! } \\ \text { Goslings: Ga-ga-ga! } & \text { Honk-honk-honk! } \\ \text { Mama: Est' khotite? } & \text { Do you want to eat? } \\ \text { Goslings: Da-da-da! } & \text { Yes-yes-yes! } \\ \text { Mama: Nu, letite! } & \text { Well, fly on over! } \\ \text { Goslings: Nam nel'zia! } & \text { We can't! } \\ \text { Mama: Pochemu? } & \text { Why not? } \\ \text { Goslings: Seryi volk za goroi } & \text { The gray wolf behind the hill } \\ \quad \text { Ne puskaet nas domoi. } & \text { Won't let us come home.(11) }\end{array}$

Another variant ends in the following way:

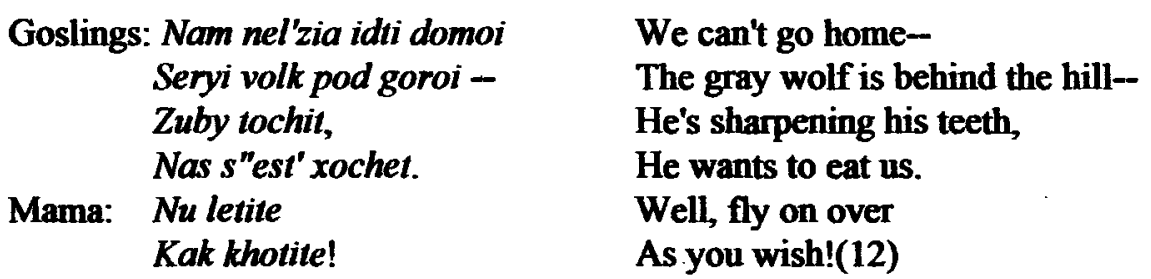

At this point, the goslings run across the field. The wolf attempts to tag as many of them as possible. Each gosling that he tags becomes a wolf. The game continues, with multiple wolves catching an ever-diminishing corps of goslings.(13) 
What does this game teach? Keeping in mind that its target audience (i.e., players) is children who are entering kindergarten or are old enough to do so, it teaches them to become independent from their mothers, which is apropos for this age. The goslings attempt to rejoin mother but often end up in the larger group of wolves; they end up with their peers rather than their family, as depicted by the "mama." The wolves work together toward one goal: increasing the group as much as possible. Although the goal is to avoid joining the group, the latter gains in importance and desirability as it grows. This may indicate that the group still holds a strong position in society. Other "wolf" games display similar characteristics. In past generations this game may have reinforced the notion of working together; it still may. In this variant, I have seen players create strategies for corralling the remaining geese or isolating the "weak" ones in order to tag them. For the children who play this and similar games, the group still apparently holds a prominent place.

Another game that I collected in 1991 also reflects the preeminence of the group. Whereas in "Gusi-gusi" the individual formed a new group, "Tretii lishnii" exemplifies the type of game where the majority of players unite against one player, making the task of joining the group more difficult.(14) Instead of one player "beating the odds" (or the rest of the players), the majority excludes the one outsider, who is quite literally outside of the group.

In "Tretii lishnii," players stand behind each other in two concentric circles. One player is denoted "Extra;" he is the chasee. The chaser is "It." As It chases the Extra, the latter may opt to replace himself with another player. To do so, the Extra stands in front of another player (in one of the circles), who then becomes Extra. In some variants, only the inner circle may be replaced, at which point the inner player steps back into the outer circle and the outer player becomes Extra.(15) I have seen and read about several variants, and have noticed that there are basic rules and regional ones.(16) For example, when players run through the circle, they must hop on one foot. When one runs outside the circle, he or she may run normally. If the player being chased is caught, he is out of the game OR becomes "it," depending on the local rules. Children create the rules for each game from a mix of "standard" rules that everyone "should" know and their own play group's rules.

Similar to "Gusi-gusi," the group "comes to the rescue" of the individual. The difference lies in each group's definition of what constitutes the desirable group. In "Gusi-gusi," the original group is desirable yet helpless to come to the aid of its members; it eventually loses power and is replaced. The "new" group (i.e. wolves), can help each other and becomes the dominant group. In "Tretii lishnii," converselly, the initial group retains power throughout the course of the game. This is further evidenced by the (unofficial) rule that when the player being chased tires, he can replace himself with 
another. In this way, the individual who is not part of the group must work harder to become part of it. Whereas the group members easily replace each other, the chaser must catch his prey in order to rejoin the group --a considerably more difficult job. This reflects village life, in a way, in that individuals from outside must work very hard to gain acceptance. This game also reinforces the notion that the group has an easier time playing, sharing the burdens so that no one individual has too hard a time. Even the imagery reinforces the notion that being part of the group is preferable to being an outsider.

In these games for young children, the message reflects society as a whole, as characterized by Douglas' criteria. Brian Sutton-Smith has noted that games "replicate the larger systems of power of which they are a part."(17) These games strengthen the notion of group importance and strength, indicating that childhood play parallels the larger social structure. As noted earlier, Russian society has traditionally stressed the group over the individual. Although these structures may be changing and the individual is gaining in importance, the group remains a strong influence on everyday life. Children realize this on some level and act it out in order to reinforce the social importance of the group.

Another game in which the group protects its members is "Boiare." Like "Tretii lishnii," an individual is pitted against another group. The difference here lies in the fact that she already belongs to another group that can aid her.(18) Players of this game range in age from 9-14. A team game, "Boiare" recreates a historical social event: marriage. Perhaps reflecting bride capture or parodying the rituals associated with fetching the bride for a village wedding, it depicts one group approaching another in order to demand a bride. Rather than coming into existence as "watered-down ritual" as the rite itself diminished in importance, this game very likely existed alongside the actual ritual, providing children an outlet to parody marriage and the ceremonies surrounding it. Folklore typically reflects history and social life; this game is no exception.(19)

Players stand in two teams, in lines facing each other, several feet apart, with hands linked.

Each team in turn yells or sings its lines while walking forward and back as a group:

Team A: Boiare, a my $k$ vam prishli, Molodye, a my $k$ vam prishli.

Team B: Boiare, a zachem prishli, Molodye, a zachem prishli?

Team A: Boiare, nam nevesta nuzhna, Molodye, nam nevesta nuzhna.

Team B: Boiare, a kakaia vam muzhna, Molodye, a kakaia vam nuzhna?
Boyars, we have come to you, Young ones, we have come to you. Boyars, why have you come, Young ones, why have you come? Boyars, we need a bride, Young ones, we need a bride. Boyars, which one do you need, Young ones, which one do you need?

Then the team chooses a "bride." 
Team A: Boiare, nam vot eta muzhna, Molodye, nam vot eta mila.
Boyars, we like that one, Young ones, we like that one.

The other team, of course, does not wish to surrender her. They reply with excuses: .

Team B: Boiare, u nei zubki boliat, Molodye, u nei zubki boliat.

Team A: Boiare, a my $k$ doktoru svedem, Molodye, a my $k$ doktoru svedem.
Boyars, she has a toothache, Young ones, she has a toothache. Boyars, we'll take her to the doctor, Young ones, we'll take her to the doctor.

This goes on with several excuses, ultimately ending with these words:

Team A: Boiare, ona churochka u nas, Molodye, ona durochka u nas.

Team B: Boiare, ne voliaite duraka, Vydavaite nam nevestu novsegda.
Boyars, she's our stupid one, Young ones, she's our stupid one. Boyars, don't hold on to the stupid one, Send us the bride forever.(20)

In one major variant, the chosen player then runs toward the opposing team and attempts to break through their "chain." If she is unsuccessful, she must join the opposing team. If she is successful, she may return to her team with an opposing player in tow as a prize. In this game one group is forced to yield up individuals, which they do quite unwillingly. Surrendering a group member to an unknown group is dangerous, as no other group will care for her like her own. This teaches players about the role, significance, and strength of group bonds. The game demonstrates this physically by requiring the "stranger" to sever the group's bonds by breaking through the chain of hands.

As in "Tretii lishnii," the group comes to the aid of the individual.(21) The individual, however, is ultimately responsible for her own fate. She must break through the barriers of the other group in order to return to her own group. This game is currently extremely popular in elementary schools in Pskov, where I carried out my fieldwork.(22) This may indicate that children are, on some level, realizing that the individual is gaining power - the strength required to break through the group hints that there is some emphasis on the individual. The notion of the strength of the group, however, remains more powerful. While the individual is gaining, the group still stands strong.

\section{REFLECTIONS OF LIFE}

I have asserted that these three types of games, exemplified by the examples given, reflect the importance of the group in children's self-socialization. Of course children have played and continue to play other, more individually oriented "tag-type" games. I certainly cannot purport that group games are taking over or have been the sole type of games for generations. Rather, that the grouporiented games persist indicates that they fulfill a need (one of many) in the socialization of the players. The reinforcement of the group is only one aspect of this socialization, but it is apparently important to children, as evidenced by the fact that they still play such games. If the players did not sense on some level that these skills were useful, they would shun the games.(23) 
The game types discussed all depict different types of group dynamics. "Gusi-gusi" facilitates the process of leaving mother's protective wing to join the potentially dangerous (yet supportive) group of wolves. "Tretii lishnii" demonstrates the difficulties encountered when one does not belong to the group, as well as the strict rules associated with rejoining.(24) "Boiare" reflects the larger social construct of out-marriage, directly parodying and mirroring the feelings associated with growing up and leaving home. These games are perpetuated because they reinforce social norms that children deem important. Several folk games indicate this in their structure. Although Russia is currently changing economically and socially, allowing the individual higher status in the group, children still recognize the importance of the group and its dynamic. The older ideals remain because children need something relatively stable to cling to, especially in times of social duress. Folklore is traditional; it reflects social ideals. The more things change, the more children's folklore stays the same, by necessity. Hence even with the rise of the individual as a significant component of Russian society, the group remains a dominant factor.

One must keep in mind, however, that even in light of the cultural implications associated with children's games, children perceive play as simply pretend. As far as they are concerned, they play to have fun. Reinforcement of social constructs through the unofficial education of play is a bonus.

Notes

1. Source 103: Ira Boreiko, age 19, 1st year, PGPI. Collected 29 November 1995.

2. This paper deals primarily with some of the observations that I have made regarding the games that I have collected in the course of my fieldwork.

3. S.A. Zavarzhin, "Aggressive Fantasies in Childhood and Adolescence, "Russian Education and Society 36 (Oct. 1994), p. 30.

4. Mary and Herbert Knapp, One Potato. Two Potato (New York: W.W. Norton \& Company, 1976) p. 49.

5. Elliott Avendon and Brian Sutton-Smith, The Study of Games (New York: John Wiley \& Sons, Inc., 1971), p. 6.

6. Brian Sutton-Smith, "Towards an Anthropology of Play," in Steven Phillips, Jr., ed., Studies in the Anthropology of Play: Papers in Memory of B. Allan Tindall (West Point, NY: Leisure Press, 1977), p. 228.

7. Mary Douglas, Natural Symbols (New York: Pantheon Books, 1982), p. 65.

8. Douglas, p. 59.

9. This game is also called "Gusi-lebedi" ("Geese-swans") and "Gusi $i$ volk" ("Geese-wolf"). Cf. "Karava"" in B.N. Putilov, editor, Detskii poeticheskii fol'klor (S.-Peterburg, Dmitrii Bulanin, 1997), pp. 369 and 539. And "Gorelki," in Putilov, pp. 361-62 and 534-35. The latter more loosely fits the game type. Putilov includes several such games, as does . S.K. Iakub in Yspomnim zabytye igry (Moskva: “Detskaia literatura,” 1990). 
10. Cf. "Volk i detr" in Putilov, p. 363 and "Igra s volkom" in A. M. Novikova, Russkoe narodnoe poeticheskoe tvorchestvo (Moscow: Vysshaia shkola," 1987), pp. 71-72.

11. I first encountered this particular variant at Ferrum College in 1982. Collected by the author from Sasha Saari, a Russian teacher at the college.

12. B.N. Putilov, p. 364. Cf. Iakub, 94-99.

13. This is only one variant; several others exist.

14. Cf. "Kostroma" in Putilov, pp. 366 and 538; and "Boiare" in Putilov, pp. 367 and 539, also collected by the author from Natasha Novoselova, age 16, Moscow and Natasha Tuliakova, age 16, Moscow. July 29, 1991, at James Madison University, Harrisonburg, Virginia at the Virginia Governor's Russian Studies Academy.

15. Collected from Aleksandr Bogach, age 16, Volgograd, and Anna Kuznetsova, age 16, Volgograd. July 29, 1991, at James Madison University, Harrisonburg, VA, at the Virginia Governor's Russian Studies Academy. Aleksandr forgot part of the game; his friends filled in the gaps where he left off. I also observed Aleksandr and his friends playing this game as they taught it to American students. 16. Cf. Iakub, pp. 77-81 and S.A. Shmakov, Igra (Moskow: NV Magistr, 1992), p. 58. Shmakov calls this game "Vtoroi lishnii."

17. Sutton-Smith, "Towards an Anthropology of Play," p. 226.

18. This is as opposed to "Gusi-gusi," where the group can have no defense nor strategy.

19. V. Bakhtin, Skazki. pesni, chastushki, prislov'ia Lenigradskoi oblast: Sbornik (Leningrad:

Lenizdat, 1982), p. 8.

20. Collected by the author from Natasha Novoselova, age 16, Moscow and Natasha Tuliakova, age 16, Moscow. July 29, 1991, at James Madison University, Harrisonburg, VA, at Virginia Governor's Russian Studies Academy. Cf. Putilov, p. 367 and 539.

21. In "Tretii lishnii," I define the individual being helped as the Extra, rather than the It.

22. Interview with Barbara Jenkins, September 18,1998 . Ms. Jenkins had recently returned from teaching at the Bishkola (Bilingual School) in Pskov for two years.

23. As children master skills, they outgrow various genres of childlore, shunning them as "babyish" or "stupid."

24. Just as folk groups exhibit versatility in their unofficial rules for inclusion, it is noteworthy that this game is flexible in its rules: several local variants exist. Joining the group means jumping through different hoops, depending on the play group. 